\title{
International procedural regulation in the common interest: the role of fact-finding and evidence before the International Court of Justice
}

\author{
Regulação processual internacional no \\ interesse comum: a investigação e obtenção das \\ provas perante a Corte Internacional de Justiça
}

Paula Wojcikiewicz Almeida

\begin{abstract}
By developing international law, international courts can also contribute to the protection and promotion of community interests. The ICJ, in particular, is capable of promoting community interests by adjudicating inter-State claims. However, one of the main obstacles faced by the World Court relates to the existing tension between the bilateral nature of its own proceedings and the multilateral nature
\end{abstract}

1 Professor of International Law and EU Law at the Getulio Vargas Foundation Law School in Rio de Janeiro (FGV-Rio) since 2008. Director of the Jean Monnet Centre of Excellence on EU-South America Global Governance, sponsored by the European Commission at the Getulio Vargas Foundation Law School. Associate Researcher at the Institute of International and European Law at the Sorbonne (IREDIES). Post-doctoral visiting scholar at the Max Planck Institute for Comparative Public Law and International Law (2014). Visiting professor at the École de droit de la Sorbonne, Université Paris 1 Panthéon-Sorbonne (2019). Visiting professor at the University of Salzburg (since 2017). 
of the conflicting substantive law. Considering that procedure may guide and shape the application of substantive law, it will be argued that it should itself be interpreted and developed in a manner to ensure community interests. This article argues that the Court should assume expanded procedural powers in order to ensure the effective application of substantive law whenever community interests are at issue. Most procedural rules can be adjusted for multiparty aspects with the aim of protecting community interests and enhancing the international court's legitimacy. This article argues that two issues deserve further analysis with a view to promoting the interests of the international community: fact-finding in complex cases involving community interests, which includes the need for an independent expertise and guidance on cross-examination issues; and transparency in the production of documentary evidence and its consequences in community interests' cases.

Keywords: International Court of Justice; fact-finding and evidence; international regulation; community interests.

Resumo: Ao desenvolver o Direito Internacional, os tribunais internacionais podem também contribuir para a proteção e promoção dos interesses da comunidade. A CIJ, em particular, é capaz de promover os interesses da comunidade através do julgamento de reclamações interestatais. Contudo, um dos principais obstáculos enfrentados pelo Tribunal Mundial diz respeito à tensão existente entre a natureza bilateral dos seus próprios procedimentos e a natureza multilateral do Direito substantivo conflituoso. Considerando que o procedimento pode orientar e moldar a aplicação do direito substantivo, será defendido que ele próprio deve ser interpretado e desenvolvido de forma a assegurar os interesses coletivos. Este artigo defende que o 
Tribunal deve assumir poderes processuais alargados, a fim de assegurar a aplicação efetiva do direito substantivo sempre que estejam em causa interesses comunitários. A maioria das regras processuais podem ser ajustadas para atender a aspectos multipartidários com o intuito de proteger os interesses da comunidade e reforçar a legitimidade do Tribunal internacional. Este artigo argumenta que duas questões merecem uma análise mais aprofundada com vista a promover os interesses da comunidade internacional: o apuramento de fatos em casos complexos envolvendo interesses comunitários, que inclui a necessidade de uma perícia e orientação independentes sobre questões de contra interrogatório; e a transparência na produção de provas documentais e suas consequências em casos de interesses comunitários.

Palavras-chave: Corte Internacional de Justiça; apuração de fatos e evidência; regulação internacional; interesses comunitários

\section{Introduction}

This article is part of a research project globally devoted to the enhancement of International Court of Justice (ICJ) procedures for litigating in the common interest. The objective of the research project is to access the ways in which ICJ procedural rules can be adjusted and tailored for multiparty aspects in order to protect community interests and enhance international court's legitimacy. With a view to responding to this challenge, this research project identified the need to expand the following procedural rules: intervention of third parties; participation of non-State actors as amici curiae; fact-finding powers; and rules of evidence.

The article intitled 'Enhancing ICJ procedures for litigating in the common interest: third-party intervention 
and amicus curiae briefs' (Revista de Direito da Cidade, vol. $11, \mathrm{n}^{\mathrm{O}} 1$ ) dealt with the issues of third-party intervention and amicus curiae briefs; while the current paper touches upon procedural rules regarding fact-finding powers and evidence. Both works share the same theoretical framework and depart from the same idea according to which the role of international courts is not limited to the bilateral dispute settlement between States ${ }^{2}$; they perform other important functions, such as the development of normative expectations - in order to achieve international adjudication's full potential, which is the realisation of justice ${ }^{3}$. By developing international law, the role of ICTs encompasses the protection and development of the international community and its values ${ }^{4}$.

Still having the ICJ as a focus, this analysis will address the Court's ability to promote 'community interests' ${ }^{5}$ by

2 BOGDANDY, A. v.; VENZKE, I. In Whose Name? A Public Law Theory of International Adjudication. Oxford: OUP, 2014. p. 15.

3 BOGDANDY, A. v.; VENZKE, I. In Whose Name? A Public Law Theory of International Adjudication. Oxford: OUP, 2014. p. 15. See also HELFER, L. R.. The Effectiveness of International Adjudicators. In: ALTER, K. J.; ROMANO, C.; SHANY, Y. (Eds.). The Oxford Handbook of International Adjudication. OUP, 2014 and ALVAREZ, J. E. What Are International Judges For? The Main Functions of International Adjudication. In: ALTER, K. J.; ROMANO, C.; SHANY, Y. (Eds.). The Oxford Handbook of International Adjudication. OUP, 2014. 158 at 464.

4 See SIMMA, B.. From Bilateralism to Community Interest in International Law. Leiden: Martinus Nijhoff, 1994. (Recueil des Cours de l'Académie de Droit International, 250). p. 233-242; BOGDANDY, A. v.; VENZKE, I. In Whose Name? A Public Law Theory of International Adjudication. Oxford: OUP, 2014. p. 38; LAUTERPACHT, H.. The Development of International Law by the International Court. London: Stevens \& Sons Limited, 1958; CANÇADO TRINDADE, A. A.. International Law for Humankind: Towards a New Jus Gentium. Leiden, Boston: Martinus Nijhoff, 2010. (The Hague Academy of International Law Monographs, 6).

5 'Community interests' and 'common concern' tend to transcend states' individuals' interests and ensure the protection of the international 
adjudicating inter-state claims ${ }^{6}$. Although not reflecting an integrated regime capable of protecting specific values, such as the European Court of Human Rights or the InterAmerican Court of Human Rights, the ICJ's recognition and application of erga omnes obligations is in itself a patent example of its prominent role in the protection of the interests of the international community. Nevertheless, the Court's intrinsic tension between state consent and global values may undermine its capacity to promote public interest ${ }^{7}$. Indeed, the tension between the multilateral nature of the conflicting substantive law and the bilateral nature of its own proceedings may generate significant backlashes 8 .

community (SIMMA, B.. From Bilateralism to Community Interest in International Law. Leiden: Martinus Nijhoff, 1994. (Recueil des Cours de l'Académie de Droit International, 250). p. 233-242; BENZING, M. Community Interests in the Procedure of International Courts and Tribunals. The Law \& Practice of International Courts and Tribunals, Leiden, vol. 5, n. 3, p. 369-408, 2006. p. 217-384). For more details, see WOJCIKIEWICZ ALMEIDA, P. Enhancing ICJ procedures for litigating in the common interest: third-party intervention and amicus curiae briefs. Revista de Direito da Cidade, Rio de Janeiro, vol. 11, n. 1, 2019. p. 331.

6 NOLLKAMPER, A. International Adjudication of Global Public Goods: The Intersection of Substance and Procedure. The European Journal of International Law, vol. 23, n. 3, 2012. p. 769-770.

7 In the South West Africa cases (Ethiopia v South Africa; Liberia v South Africa), the ICJ rejected the existence of an actio popularis or a 'right resident in any member of a community to take legal action' for vindicating a public interest. See INTERNATIONAL COURT OF JUSTICE. South West Africa (Ethiopia v South Africa; Liberia v South Africa). Judgment: Second Phase, 1966. ICJ Reports p. 6, para. 88. See BENZING, M.. Community Interests in the Procedure of International Courts and Tribunals. The Law \& Practice of International Courts and Tribunals, Leiden, vol. 5, n. 3, p. 369-408, 2006. p. 376; see also KLABBERS, J. The Community Interest in the Law of Treaties: Ambivalent Conceptions. In: FASTENRATH, U.; GEIGER, R.; KHAN, D. et al (Eds.). From Bilateralism to Community Interest: Essays in Honour of Judge Bruno Simma. Oxford: OUP, 2011. p. 768.

8 Examples of backlashes in ICJ case law can be found in the introduction of the previous article published in this journal dealing with the topic of thirdparty intervention and amicus curiae briefs: WOJCIKIEWICZ ALMEIDA, P. 
This paper argues that there is a disconnection between community interests and procedure, which has not been attuned to reflect contemporary international law challenges deriving from community interests ${ }^{9}$. Procedures can be interpreted, enhanced, voire designed in order to ensure the promotion of community interests ${ }^{10}$. However, it appears that the ICJ has been very modest in utilising its powers to expand procedural rules beyond its mandate to ensure the application of substantive law reflecting community interests ${ }^{11}$.

Judicial procedures could be expanded in a way to strengthen the democratic legitimation of judicial decisions. Therefore, in contentious cases involving litigation in the 'common interest', a diverse range of procedural issues may raise particular concerns, such as intervention of third parties $^{12}$, participation of non-state actors as amici curiae,

Enhancing ICJ procedures for litigating in the common interest: third-party intervention and amicus curiae briefs. Revista de Direito da Cidade, Rio de Janeiro, vol. 11, n. 1, 2019. p. 331.

9 See, generally, CANNIZZARO, E.; BONAFÉ, B. I. Of Rights and Remedies: Sovereign Immunity and Fundamental Human Rights. In: FASTENRATH, U.; GEIGER, R.; KHAN, D. et al (Eds.). From Bilateralism to Community Interest: Essays in Honour of Judge Bruno Simma. Oxford: OUP, 2011. From a more theoretical point of view, see: BAMBIRRA, Felipe Magalhães. Soberania revisitada: construção histórico-filosófica e aproximativa entre direitos humanos e soberania através da dialética do reconhecimento. Revista Brasileira de Estudos Políticos, vol. 114, 2017; FORNASIER M. O., MENDES, T. M.. Constitucionalismo e globalização: entre ordens internas e externas de direitos. Revista Brasileira de Estudos Políticos, vol. 113, 2016.

10 NOLLKAMPER, A. International Adjudication of Global Public Goods: The Intersection of Substance and Procedure. The European Journal of International Law, vol. 23, n. 3, 2012. p. 787-788.

11 MCWHINNEY, E. The International Court of Justice and International Law-Making: The Judicial Activism/Self-Restraint Antinomy. Chinese Journal of International Law. vol. 5, 2006. p. 3.

12 PALCHETTI, P. Opening the International Court of Justice to Third States: 
fact-finding powers and rules of evidence ${ }^{13}$. According to the Court's survey conducted as a preparation to the Seminar held on the occasion of the 70th Anniversary of the Court's first inaugural sitting, the topic of evidence and fact finding has been identified as the most questionable one, thereby requiring important reform proposals, notably regarding the Court's treatment of scientific cases ${ }^{14}$. The establishment of fact and rules of evidence within the ICJ are both relevant for the legitimation of international adjudication, notably when community interests are concerned ${ }^{15}$.

Intervention and Beyond. In: FROWEIN, J. A.; WOLFRUM, R. (Eds.). Max Planck Yearbook of United Nations Law. Kluwer Law International, 2002, vol. 6. p.139-181. p. 139.

13 BENZING, M.. Community Interests in the Procedure of International Courts and Tribunals. The Law \& Practice of International Courts and Tribunals, Leiden, vol. 5, n. 3, p. 369-408, 2006. p. 383-384, 389; TEITELBAUM, R. Recent Fact-Finding Developments at the International Court of Justice. The Law and Practice of International Court and Tribunals, Leiden, vol. 6, 2007. p. 119; KLEIN, N. S. Multilateral Disputes and the Doctrine of Necessary Parties in the East Timor Case. Yale Journal of International Law. vol, 21, n. 2, 1996. p. 329; FOSTER, C. E.. Science and the Precautionary Principle in International Courts and Tribunals. Expert Evidence, Burden of Proof and Finality. Cambridge: Cambridge University Press, 2011; LACHS, M. H.. Evidence in the Procedure of the International Court of Justice: Role of the Court. In: Bello, E. G.; Ajibola, B. A. (Eds.). Essays in Honour of Judge Taslim Olawale Elias. Leiden: Martinus Nijhoff, 1993. p. 205.

14 See CRAWFORD, J.; KEENE, A. Editorial. Journal of International Dispute Settlement, Oxford, vol. 7, 2016. p. 225.

15 BOGDANDY, A. v.; VENZKE, I. On the Democratic Legitimation of International Judicial Lawmaking. German Law Journal, Cambridge, vol. 12, n. 5, p. 1341-1370, 2011. p. 1362; BENZING, M.. Community Interests in the Procedure of International Courts and Tribunals. The Law \& Practice of International Courts and Tribunals, Leiden, vol. 5, n. 3, p. 369-408, 2006. p. 383; See also TEITELBAUM, R. Recent Fact-Finding Developments at the International Court of Justice. The Law and Practice of International Court and Tribunals, Leiden, vol. 6, 2007. p. 119; KLEIN, N. S. Multilateral Disputes and the Doctrine of Necessary Parties in the East Timor Case. Yale Journal of International Law. vol, 21, n. 2, 1996. p. 329; 
This article argues that two issues deserve further analysis with a view to promoting the interests of the international community: fact-finding in complex cases involving community interests, which includes the need for an independent expertise and guidance on crossexamination issues (B); and transparency in the production of documentary evidence and its consequences in community interests' cases (C).

\section{B. Fact-finding in complex cases involving com- munity interests}

In the Pulp Mills on the River Uruguay case ${ }^{16}$, the Court was largely criticised due to a lack of sufficient evidence since it officialy relied on expertise provided by the parties. The scientific character of this dispute - involving water quality, maintenance of ecological balance and pollution - required 'scientific fact-finding', which has been perceived as a distinct category of fact-finding in international adjudication ${ }^{17}$. Given

FOSTER, C. E.. Science and the Precautionary Principle in International Courts and Tribunals. Expert Evidence, Burden of Proof and Finality. Cambridge: Cambridge University Press, 2011; LACHS, M. H.. Evidence in the Procedure of the International Court of Justice: Role of the Court. In: Bello, E. G.; Ajibola, B. A. (Eds.). Essays in Honour of Judge Taslim Olawale Elias. Leiden: Martinus Nijhoff, 1993. p. 205.

16 NTERNATIONAL COURT OF JUSTICE. Pulp Mills on the River Uruguay (Argentina v. Uruguay). Judgment, 2010. ICJ Reports p. 14. For an analysis of the case, see MALJEAN-DUBOIS, S.; RICHARD, V. Pulp Mills on the River Uruguay (Argentina v. Uruguay), 2006. In: ALMEIDA, PAULA W; SOREL, JEAN-MARC. (Eds.). Latin America and the International Court of Justice: Contributions to International Law. Routledge, 2017.

17 MBENGUE, M. M.. Scientific Fact-finding at the International Court of Justice: An Appraisal in the Aftermath of the Whaling Case. Leiden Journal of International Law. Cambridge, vol. 29, 2016. p. 532; MBENGUE, M. M.. International Courts and Tribunals as Fact-Finders: The Case of Scientific Fact-Finding in International Adjudication. Loyola of Los Angeles 
its peculiar character, 'scientific fact-finding' ought not to be treated as traditional fact-finding ${ }^{18}$.

As acknowledged by Judge Cançado Trindade in his separate opinion in the Pulp Mills case, 'international environmental law is attentive to human health' ${ }^{\prime 19}$. Contemporary human rights protection and environmental protection are necessarily linked and reflect issues of general public interest ${ }^{20}$. Rules and obligations referring to the protection of the environment are adopted in the 'common superior interest of humankind'21.

In such cases involving the protection of the environment, which is also considered a community interest, the dissenting opinion of Judges Al-Khasawneh and Simma could not be more appropriate: the Court should have either appointed its own experts or had party-appointed experts subjected to cross-examination ${ }^{22}$. In its separate opinion in the Gabčíkovo-Nagymaros case ${ }^{23}$, Judge Weeramantry also stressed that rules governing inter partes litigation may be

International and Comparative Law Review. vol. 34, n. 1, 2011. p. 53.

18 MBENGUE, M. M.. Scientific Fact-finding at the International Court of Justice: An Appraisal in the Aftermath of the Whaling Case. Leiden Journal of International Law. Cambridge, vol. 29, 2016. p. 533.

19 INTERNATIONAL COURT OF JUSTICE. Pulp Mills on the River Uruguay (Argentina v. Uruguay). Judgment, 2010. Separate opinion of Judge Cançado Trindade. ICJ Reports p. 14, para 154.

20 INTERNATIONAL COURT OF JUSTICE. Pulp Mills on the River Uruguay (Argentina v. Uruguay). Judgment, 2010. Separate opinion of Judge Cançado Trindade. ICJ Reports p. 14, paras 159 and 167.

21 INTERNATIONAL COURT OF JUSTICE. Pulp Mills on the River Uruguay (Argentina v. Uruguay). Judgment, 2010. Separate opinion of Judge Cançado Trindade. ICJ Reports p. 14, para 173.

22 See INTERNATIONAL COURT OF JUSTICE. Pulp Mills on the River Uruguay (Argentina v. Uruguay). Judgment, 2010. Joint Dissenting Opinion of Judges Al-Khasawneh and Simma. ICJ Reports p. 14, para 8

23 INTERNATIONAL COURT OF JUSTICE. Gabčíkovo-Nagymaros Project (Hungary v Slovakia). Judgment, 1997. ICJ Reports, p. 7. 
inadequate when adjudicating environmental issues that affect interests of humanity ${ }^{24}$. Indeed, the Court's traditional approach to fact-finding is clearly not suitable in complex scientific cases or in cases in which 'a high degree of scientific uncertainty subsists ${ }^{25}$, i.e., in cases involving the interests of the international community.

In order for the Court to reframe its proceedings on factfinding issues with a view to protecting the interests of the international community, the following proposals could be made: firstly, the Court should ban from its practice the use of 'experts-fantômes' (1); secondly, experts should appear before the Court as witnesses and not as counsels (2); and thirdly, the Court should make more active use of its powers to appoint an independent expert whenever community interests are at stake (3).

24 INTERNATIONAL COURT OF JUSTICE. Gabčíkovo-Nagymaros Project (Hungary v Slovakia). Judgment, 1997. Separate Opinion of Judge Weeramantry. ICJ Reports, p. 7, 118.

25 See INTERNATIONAL COURT OF JUSTICE. Pulp Mills on the River Uruguay (Argentina v. Uruguay). Judgment, 2010. Joint Dissenting Opinion of Judges Al-Khasawneh and Simma. ICJ Reports p. 14, para 17. See also the scholarship in this regard: MALINTOPPI, L. Fact Finding and Evidence Before the International Court of Justice (Notably in Scientific-Related Disputes). Journal of International Dispute Settlement, Oxford, vol. 7, 2016. p. 421; MBENGUE, M. M.. International Courts and Tribunals as FactFinders: The Case of Scientific Fact-Finding in International Adjudication. Loyola of Los Angeles International and Comparative Law Review. vol. 34, n. 1, 2011. p. 53; MBENGUE, M. M.. Scientific Fact-finding at the International Court of Justice: An Appraisal in the Aftermath of the Whaling Case. Leiden Journal of International Law. Cambridge, vol. 29, 2016. p. 529; DEVANEY, J. G.. Fact-Finding before the International Court of Justice. Cambridge: Cambridge University Press, 2016; ALVAREZ, J. E. Are International Judges Afraid of Science?: A Comment on Mbengue. Loyola of Los Angeles International and Comparative Law Review. vol.34, n. 1, 2011. p. 81 . 


\section{Eliminating 'experts-fantômes'}

The Court has been informally assisted by 'cartographers, hydrographers, geographers, linguists' and other legal experts, without making this public knowledge ${ }^{26}$. Such recurrent practice deprives the Court's proceedings of transparency, openness and procedural fairness ${ }^{27}$. Moreover, Parties are not able to comment upon the opinion rendered by such 'experts-fantômes' or cross-examine them during oral proceedings. Yet Article 67 (2) of the Rules and Article 50 of the Statute expressly allow parties to comment upon every expert opinion arranged by the Court. Denying access to such technical opinions is contrary to due process and to the good administration of justice. Even if Judges rely on 'invisible experts', the Parties should always be informed 'whether consultants have been engaged by the Court and according to which mandate ${ }^{28}$, as suggested by Judge Gaja.

26 JENNINGS, R. Y. International Lawyers and the Progressive Development of International Law. In: MAKARCZYK, J. (Ed.). Theory of International at the Threshold of the $21^{\text {st }}$ Century: Essays in Honour of Krzystof Skubiszewski. Leiden: Matinus Nijhoff, 1996. p. 416 and COUVREUR, P. Le règlement juridictionnel. In SFDI (Ed.). Le processus de delimitation maritime: étude d'un cas fictif. Colloque international de Monaco du 27 au 29 mars 2003, 2004, p. 349, 384. Op. Cit. INTERNATIONAL COURT OF JUSTICE. Pulp Mills on the River Uruguay (Argentina v. Uruguay). Judgment, 2010. Joint Dissenting Opinion of Judges Al-Khasawneh and Simma. ICJ Reports p. 14, para. 14.

27 INTERNATIONAL COURT OF JUSTICE. Pulp Mills on the River Uruguay (Argentina v. Uruguay). Judgment, 2010. Joint Dissenting Opinion of Judges Al-Khasawneh and Simma. ICJ Reports p. 14, para 14; TAMS, C.. Article 50. In: ZIMMERMANN, A.; TOMUSCHAT, C.; OELLERS-FRAHM, K. (Eds.). The Statute of the International Court of Justice: A Commentary. Oxford: OUP, 2006. p. 1109 and 1118; PEAT, D.. The Use of Court-Appointed Experts by the International Court of Justice. British Yearbook of International Law, Oxford, vol. 84, n. 1, p.271-303, 2014. p. 300.

28 GAJA, G. Assessing Expert Evidence in the ICJ. The Law and Practice of International Courts and Tribunals. vol. 15, 2016. p. 414. 
As a general policy, the recourse to 'experts-fantômes' should be eliminated from the Court's practice ${ }^{29}$, particularly in cases involving community interests. Also, it would be desirable for the Court to make 'a general policy statement restricting the use of "invisible" experts' for the sake of transparency ${ }^{30}$. Such criticism appears to have resonated well with the Court and paved the way for it to avoid recourse to 'experts-fantômes' in recent cases involving scientific evidence, such as in the Whaling in the Antarctic case ${ }^{31}$. Arguably, ICJ's proceedings should encompass a new Rule condemning the use of experts-fantômes.

\section{Experts should appear as witnesses with all related consequences}

The practice of including experts as counsel or advocates before the ICJ has been extensively criticised by academia and by the Court itself, notably because advocates are not subject to cross-examination and to questions from the bench ${ }^{32}$. In the Temple of Preah Vihear case, the Court did

29 This point was made clear by Philippe Sands at the Seminar held at the International Court of Justice, on 18 and 19 April 2016, on the occasion of the 70th Anniversary of the Court's first inaugural sitting (survey conducted in preparation for the Seminar in 2015), available in CRAWFORD, J.; KEENE, A. Editorial. Journal of International Dispute Settlement, Oxford, vol. 7, 2016. p. 225

30 GAJA, G. Assessing Expert Evidence in the ICJ. The Law and Practice of International Courts and Tribunals. vol. 15, 2016. p. 414.

31 INTERNATIONAL COURT OF JUSTICE. Whaling in the Antarctic (Japan/ Australia: New Zealand intervening). Judgment: Merits, 2014. ICJ Reports p. 226.

32 SANDOVAL COUSTASSE, J. G.;SWEENEY-SAMUELSON, E. Adjudicating Conflicts Over Resources: The ICJ's Treatment of Technical Evidence in the Pulp Mills Case. Goettingen Journal of International Law, vol. 3, n. 1, 2011. p. 447; PAYNE, C. Mastering the Evidence: Improving Fact Finding 
not consult experts for the delimitation of the boundary; the sole experts in the case acted as counsels of the parties. The choice of the Court not to appoint its own experts was criticised by dissenting Judge $\mathrm{Koo}^{33}$. The Court followed the same path in Kasikili/Sedudu Island case and solely relied on the opinions of experts who were acting as counsels of the parties ${ }^{34}$. The Parties applied same practice of including experts on counsel teams in the Pulp Mills case. Without appointing its own experts under Art. 50 of the Statute, the Court made it clear that experts 'should testify before the Court as experts, witnesses or in some cases in both capacities, rather than counsel', for the reasons indicated above $^{35}$. Therefore, the practice of experts appearing as counsel should be definitely eliminated ${ }^{36}$.

The Court's new approach in the Whaling case reflected the importance of having experts as witnesses. Despite representing a category not foreseen in the Statute or the Rules ${ }^{37}$, the Court has received the testimony of

by International Courts. Environmental Law Review. vol. 41, 2011. p. 1191; FOSTER, C. E.. New Clothes for the Emperor? Consultation of Experts by the International Court of Justice. Journal of International Dispute Settlement, Oxford, vol. 5, n. 1, p. 139-173, 2014. p. 139; DEVANEY, J. G.. Fact-Finding before the International Court of Justice. Cambridge: Cambridge University Press, 2016.

33 INTERNATIONAL COURT OF JUSTICE. Case concerning the Temple of Preah Vihear (Cambodia v. Thailand). Judgment, 1962. Dissenting opinion of Judge Wellington Koo. ICJ Reports p. 75, para 100.

34 INTERNATIONAL COURT OF JUSTICE. Kasikili/Sedudu Island (Botswana v. Namibia). Judgment, 1999. Separate Opinion of Judge Oda. ICJ Rep p. 1045, 1142.

35 INTERNATIONAL COURT OF JUSTICE. Pulp Mills on the River Uruguay (Argentina v. Uruguay). Judgment, 2010. ICJ Reports p. 14, para 167.

36 DEVANEY, J. G.. Fact-Finding before the International Court of Justice. Cambridge: Cambridge University Press, 2016. 230.

37 The term 'expert witness' 'refers to a person who can testify both as to knowledge of facts, and also give an opinion on matters upon which he or 
expert witnesses in a growing number of $\operatorname{cases}^{38}$, notably in the Whaling case. In the latter, the ICJ was confronted with complex scientific issues that required the opinion of experts $^{39}$. Such experts, appointed by the parties as witnesses, were examined, cross-examined, and were also questioned by Judges ${ }^{40}$. In the absence of a specific procedure for the examination and cross-examination of experts either in the Rules or in the Practice Direction ${ }^{41}$, the President of the

she has expertise' (HIGGINS, R. Speech by H.E. Judge Rosalyn Higgins to the Sixth Committee of the United Nations General Assembly. 2 nov. 2007. p. 6.

38 See Corfu Channel case (United Kingdom v. Albania) [1949]; Case concerning the Temple of Preah Vihear (Cambodia v. Thailand) [1962]; South West Africa cases (Ethiopia v. South Africa; Liberia v. South Africa) [1966]; and more recent cases, such as Certain Activities Carried Out by Nicaragua in the Border Area (Costa Rica v. Nicaragua) [2015] and Construction of a Road in Costa Rica along the San Juan River (Nicaragua v. Costa Rica) [2015]. In these cases, the Court went further to detail the procedure to be followed for the examination of experts.

39 FOSTER, C. E.. New Clothes for the Emperor? Consultation of Experts by the International Court of Justice. Journal of International Dispute Settlement, Oxford, vol. 5, n. 1, p. 139-173, 2014. p. 146-9. See also TOMKA. P. Speech by H.E. Judge Peter Tomka, President of the International Court of Justice, to the Sixth Committee of the United Nations General Assembly. 31 out. 2014. p.2.

40 INTERNATIONAL COURT OF JUSTICE. Whaling in the Antarctic (Japan/ Australia: New Zealand intervening). Judgment: Merits, 2014. ICJ Reports p. 226, para. 20-1. According to Art. 64 (b) of the Rules, experts (including those appointed by the parties) are required to declare that their statements will be made in accordance with their 'sincere belief'.

41 The Statute and the Rules do not provide sufficient information on the legal regime governing the examination of experts and witnesses. See, e.g., Articles 58 and 65 of the Rules of Court. See MALINTOPPI, L. Fact Finding and Evidence Before the International Court of Justice (Notably in Scientific-Related Disputes). Journal of International Dispute Settlement, Oxford, vol. 7, 2016. p. 426; MBENGUE, M. M.. Scientific Fact-finding at the International Court of Justice: An Appraisal in the Aftermath of the Whaling Case. Leiden Journal of International Law. Cambridge, vol. 29, 2016. p. 544. 
Court made an effort to establish a detailed and transparent procedure of examination, cross-examination and reexamination $^{42}$. Judge Tomka emphasized that the Whaling case "constitutes further and incontrovertible proof that the Court can deal with vast amounts of highly technical scientific evidence in a cogent and methodical fashion" ${ }^{\prime 3}$. Indeed, after the Whaling case and Construction of a Road and Certain Activities cases, the Court has demonstrated that it is fully engaged with evidence ${ }^{44}$.

However, there is still room for refinement, notably of the rules governing the appointment and examination/ cross-examination of experts ${ }^{45}$. As for the former, it is often

42 See MBENGUE, M. M.. Scientific Fact-finding at the International Court of Justice: An Appraisal in the Aftermath of the Whaling Case. Leiden Journal of International Law. Cambridge, vol. 29, 2016. p. 542. Drawing on the Court's practice in this regard, the examination of experts/witnesses generally includes four phases: examination by the party calling the expert/witness; cross-examination by the other party; re-examination by the original party; and a round of questioning from the judges (ROSENNE, S. The Law and Practice of the International Court. Leiden: Martinus Nijhoff, 1985).

43 TOMKA. P. Speech by H.E. Judge Peter Tomka, President of the International Court of Justice, to the Sixth Committee of the United Nations General Assembly. 31 out. 2014. p.2.

44 MALINTOPPI, L. Fact Finding and Evidence Before the International Court of Justice (Notably in Scientific-Related Disputes). Journal of International Dispute Settlement, Oxford, vol. 7, 2016. p. 443. It has been noted that the cross-examination of witnesses in Construction of a Road and Certain Activities cases did not proceed as smoothly as in the Whaling case (DEVANEY, J. G.. Fact-Finding before the International Court of Justice. Cambridge: Cambridge University Press, 2016. p. 229).

45 MBENGUE, M. M.. Scientific Fact-finding at the International Court of Justice: An Appraisal in the Aftermath of the Whaling Case. Leiden Journal of International Law. Cambridge, vol. 29, 2016. p. 542. See also DEVANEY, J. G.. Fact-Finding before the International Court of Justice. Cambridge: Cambridge University Press, 2016; LIMA, L. C. Expert Advisor or nonvoting adjudicator? The potential function of assessors in the procedure of the international court of justice. Rivista di Diritto Internazionale. vol. 99, n. 4, 2016. p. 1124; MALINTOPPI, L. Fact Finding and Evidence Before 
proposed that the Court should formalize a procedure that ensures more transparency and involves the parties at every stage of the process, drawing on the practice of the $\mathrm{WTO}^{46}$. Regarding the examination and cross-examination of experts, which is essential for the Court to clarify areas of uncertainty and to test the accuracy and reliability of the expert's evidence ${ }^{47}$, the doctrine has been insisting that the Court could provide greater guidance to the parties by providing specific rules for cross-examination prior to and during the hearing. Clear guidance and information on what is required of all parties involved (witnesses, experts, counsel and judges) is essential for the cross-examination process to function properly ${ }^{48}$. The Court's relaxed case-bycase approach does not provide enough guidance and does not contribute to the sound administration of justice ${ }^{49}$.

Specific proposals include the need to clarify the order of speaking of experts acting as witnesses and the allocation of time, according to the Court's recent jurisprudence (Construction of a Road and Certain Activities cases) ${ }^{50}$.

the International Court of Justice (Notably in Scientific-Related Disputes). Journal of International Dispute Settlement, Oxford, vol. 7, 2016. p. 431.

46 Proposal made by Loreta Malintoppi on the occasion of the 70th Anniversary of the Court's first inaugural sitting (survey conducted in preparation for the Seminar in 2015), available in CRAWFORD, J.; KEENE, A. Editorial. Journal of International Dispute Settlement, Oxford, vol. 7, 2016. p. 229

47 DEVANEY, J. G.. Fact-Finding before the International Court of Justice. Cambridge: Cambridge University Press, 2016. p. 230.

48 DEVANEY, J. G.. Fact-Finding before the International Court of Justice. Cambridge: Cambridge University Press, 2016. p. 229.

49 DEVANEY, J. G.. Fact-Finding before the International Court of Justice. Cambridge: Cambridge University Press, 2016. p. 229.

50 INTERNATIONAL COURT OF JUSTICE. Certain Activities Carried Out by Nicaragua in the Border Area (Costa Rica v. Nicaragua) and Construction of a Road in Costa Rica along the San Juan River (Nicaragua v. Costa Rica). Judgment: Merits, 2015. ICJ Reports. p. 665. See MALINTOPPI, L. Fact 
Moreover, during hearings, the Court could clarify the 'prohibition of leading questions, possibility for counsel to raise objections and in what circumstances, clear guidelines on interaction with the witness outside the courtroom ${ }^{51}$. Along these lines, the Court could make it clear the principle of 'proscription of contact between counsel and witnesses' (a witness of fact or expert witness must not communicate with any counsel or representative of a party on any disputed issues until cross-examination is concluded); the 'express banning of witness proofing'; and the 'adoption of the rules on open and leading questions' ${ }^{\prime 52}$. Moreover, the conduction of cross-examination by counsels must be directed to the issues in dispute. It would also be useful if witnesses were forbidden from reading written pleadings prior to their testimony and from observing oral hearings ${ }^{\prime 53}$.

The proposals above require the adoption of a Practice Direction in order to guide the interpretation of Art. 63 and 67 of the Rules and Art. 45 of the Statute, or through a more general guidance to be available in the Court's website, drawing on the Court's practice to date.

Finding and Evidence Before the International Court of Justice (Notably in Scientific-Related Disputes). Journal of International Dispute Settlement, Oxford, vol. 7, 2016. p. 441.

51 MALINTOPPI, L. Fact Finding and Evidence Before the International Court of Justice (Notably in Scientific-Related Disputes). Journal of International Dispute Settlement, Oxford, vol. 7, 2016. p. 441

52 SARVARIAN, A. Preliminary Report. In: INTERNATIONAL LAW ASSOCIATION. Procedure of International Courts and Tribunals, 2017. (forthcoming) p. 94.

53 SARVARIAN, A. Preliminary Report. In: INTERNATIONAL LAW ASSOCIATION. Procedure of International Courts and Tribunals, 2017. (forthcoming) p. 94. 


\section{Appointing an independent expert as a regu- lar practice}

Cross-examination and questions from the bench towards expert-witnesses are certainly positive for the Court to assess the credibility of the expert's opinion and to understand the issue under examination. This however does not 'provide the Court with the scientific or technical knowledge that may be necessary to make a decision', notably when parties' experts disagree ${ }^{54}$. A preferable method for the Court to acquire scientific or technical knowledge would be the appointment of independent experts ${ }^{55}$, which has often been advocated by scholarship ${ }^{56}$.

By appointing its own experts as provided by Article 50 of the Statute and 67 of the Rules, the Court would 'establish itself as a careful, systematic court which can be entrusted with complex scientific evidence ${ }^{\prime 57}$. In its declaration,

54 GAJA, G. Assessing Expert Evidence in the ICJ. The Law and Practice of International Courts and Tribunals. vol. 15, 2016. p. 412.

55 GAJA, G. Assessing Expert Evidence in the ICJ. The Law and Practice of International Courts and Tribunals. vol. 15, 2016. p. 414.

56 RIDDEL, A.. Scientific Evidence in the International Court of Justice Problems and Possibilities. In: KLABBERS, J. (Ed.). Finnish Yearbook of International Law. Oxford: Hart Publishing, 2009. v. 20. p. 229-258. p. 257-258; FOSTER, C. E.. The Consultation of Independent Experts by International Courts and Tribunals in Health and Environmental Cases. In: KLABBERS, J. (Ed.). Finnish Yearbook of International Law. Oxford: Hart Publishing, 2009. v. 20. p. 391-420. p. 416-417; FOSTER, C. E.. New Clothes for the Emperor? Consultation of Experts by the International Court of Justice. Journal of International Dispute Settlement, Oxford, vol. 5, n. 1, p. 139-173, 2014. p. 139; MALINTOPPI, L. Fact Finding and Evidence Before the International Court of Justice (Notably in Scientific-Related Disputes). Journal of International Dispute Settlement, Oxford, vol. 7, 2016. p. 421.

57 See INTERNATIONAL COURT OF JUSTICE. Pulp Mills on the River Uruguay (Argentina v. Uruguay). Judgment, 2010. Joint Dissenting Opinion of Judges Al-Khasawneh and Simma. ICJ Reports p. 14, para. 17. 
Judge Yusuf has followed the same path and addressed the possibility of the Court making more active use of its powers to appoint its own experts to 'gain a more profound insight into the scientific and technical intricacies of the evidence submitted by the Parties'58. In addition, the appointment of a Court-expert would allow parties to expose their view by commenting on such opinions and would enhance their confidence in the technical and transparent evaluation by the Court ${ }^{59}$.

The Court's historical reluctance to use its powers under Article 50 is well-known, as already noted by Judge Wellington Koo in the Case concerning the Temple of Preah Vihear ${ }^{60}$. Indeed, in past decisions the Court only resorted to Article 50 by searching for evidence motu propio in two renowned cases ${ }^{61}$. Most recently, the Court has appointed

58 See INTERNATIONAL COURT OF JUSTICE. Pulp Mills on the River Uruguay (Argentina v. Uruguay). Judgment, 2010. Declaration of Judge Yusuf. ICJ Reports p. 14, para. 1.

59 See INTERNATIONAL COURT OF JUSTICE. Pulp Mills on the River Uruguay (Argentina v. Uruguay). Judgment, 2010. Declaration of Judge Yusuf. ICJ Reports p. 14, para. 7.

60 INTERNATIONAL COURT OF JUSTICE. Case concerning the Temple of Preah Vihear (Cambodia v. Thailand). Judgment, 1962. Dissenting opinion of Judge Wellington Koo. ICJ Reports p. 6, para 55. See also INTERNATIONAL COURT OF JUSTICE. Kasikili/Sedudu Island (Botswana v. Namibia). Judgment, 1999. Separate Opinion of Judge Oda. ICJ Rep p. 1045, para 6.

61 INTERNATIONAL COURT OF JUSTICE. Corfu Channel (United Kingdom v. Albania). Order, 1948. ICJ Reports p. 124; INTERNATIONAL COURT OF JUSTICE. Corfu Channel (United Kingdom v. Albania). Order, 1949. ICJ Reports p. 237; and INTERNATIONAL COURT OF JUSTICE. Delimitation of the Maritime Boundary in the Gulf of Maine Area (Canada v. United States of America). Order: Appointment of Expert, 1984. ICJ Reports p. 165. In Factory of Chorzów (Germany v. Poland) [PCIJ, 1928] the Committee of experts designated by the PCIJ under Art. 50 of the Statute was dissolved due to friendly settlement without rendering a report. Recourse to experts in this case was limited to the quantification of damages. For a brief analysis of the referred cases, as well as situations in which proposals by 
two experts in the case concerning the Maritime Delimitation in the Caribbean Sea and the Pacific Ocean (Costa Rica v. Nicaragua), later joined with Land Boundary in the Northern Part of Isla Portillos (Costa Rica v. Nicaragua).

In the case Maritime Delimitation in the Caribbean Sea and the Pacific Ocean (Costa Rica v. Nicaragua), the Court made an effort to follow the procedure outlined in Article 67 of its Rules. The Court informed the Parties, by an exchange of letters, of its intention to appoint independent experts to conduct a site visit, while also welcoming the Parties to present their views on (i) the subject of the expert opinion; (ii) the number and mode of appointment of the experts; and (iii) the procedure to be followed ${ }^{62}$. In response, Costa Rica requested the Court to appoint three experts and to have the opportunity to make observations on their identity, as well as to provide comments on the reports submitted before the beginning of the oral proceedings ${ }^{63}$. Finally, by its Order of 31 May 2016, the Court decided to appoint two independent experts by Order of its President after hearing the Parties. Such experts were to visit the site and to prepare a written report on their findings, which was to be communicated to the Parties to comment upon ${ }^{64}$. Since no Party objected to

the parties were not accepted by the Court, see INTERNATIONAL COURT OF JUSTICE. Pulp Mills on the River Uruguay (Argentina v. Uruguay). Judgment, 2010. Separate opinion of Judge Keith. ICJ Reports p. 14, paras 9 and 10.

62 See INTERNATIONAL COURT OF JUSTICE. Maritime Delimitation in the Caribbean Sea and the Pacific Ocean (Costa Rica v. Nicaragua). Order of 31 May 2016. ICJ Reports, para 4.

63 See INTERNATIONAL COURT OF JUSTICE. Maritime Delimitation in the Caribbean Sea and the Pacific Ocean (Costa Rica v. Nicaragua). Order of 31 May 2016. ICJ Reports, para. 5.

64 See INTERNATIONAL COURT OF JUSTICE. Maritime Delimitation in the Caribbean Sea and the Pacific Ocean (Costa Rica v. Nicaragua). Order of 31 May 2016. ICJ Reports, para 10. 
the experts identified, the Court, by an Order of 16 June, appointed two independent experts, pursuant to Art. 50 of its Statute and to Article 67 of the Rules. The referred experts were questioned by Judge Tomka and provided responses to the written comments of Costa Rica on the report they submitted on 30 April 2017.

Doubt remains on how the Court will make use of such expert opinions and what procedure it will follow in cases involving environmental law, such as the Dispute over the Status and Use of the Waters of the Silala (Chile v. Bolivia), initiated on 6 June 2016. In any case, recent practice indicates that the Court seems more encouraged to make use of Article 50 of the Statute to appoint its own experts. The Court should indeed be more active in indicating independent experts whenever it deals with factually complex cases and with those concerning interests of the international community, i.e., environmental law cases. It may be desirable for the Court to activate its powers under Art. 50, as follows: (i) when there is contestation of expert evidence by parties; (ii) when access to the evidence is restricted to only one of the parties, such as in the Corfu Channel case; (iii) when the Court does not possess scientific and technical knowledge and cannot only rely on the cross-examination of experts indicated by the parties ${ }^{65}$.

Therefore, the Court should make greater use of its power to appoint experts under Art. 50 of the Statute - as a regular practice - whenever appropriate, notably whenever community interests are at stake, possibly by adopting a practice direction in this regard ${ }^{66}$.

65 The last two situations were addressed by Judge Gaja: GAJA, G. Assessing Expert Evidence in the ICJ. The Law and Practice of International Courts and Tribunals. vol. 15, 2016. p. 415.

66 See Loretta Malintoppi, Howard Wheater and Laurence Boisson de Charzounes, 70th Anniversary of the Court's first inaugural sitting (survey conducted in preparation for the Seminar in 2015), available in 


\section{Transparency in the production and disclosu- re of documentary evidence}

The issue of requests for disclosure of evidence is also relevant to the protection of community interests by international courts. This has motivated an intense debate in the Bosnian and Croatian Genocide cases, which also dealt with matters involving community interests - the protection of human rights. However, the debate regarding the powers of the Court to draw adverse inferences towards nonproduction of documents predates the Genocide cases and is worth revisiting (1). In any case, the ICJ could make more active use of its power to request information proprio motu, as well as to grant discovery requests with all its related consequences (2).

\section{Nonproduction of evidence and the possibility of drawing adverse inferences}

In the Corfu Channel case, the Court found that a State victim of a breach in international law is often unable to furnish direct proof of facts that give rise to responsibility, notably in situations in which the other State exercises exclusive control over a territory. Therefore, the State victim 'should be allowed a more liberal recourse to inferences of fact and circumstantial evidence ${ }^{\prime 67}$. However, in the Court's view, the use of inferences for assessing the truth must

CRAWFORD, J.; KEENE, A. Editorial. Journal of International Dispute Settlement, Oxford, vol. 7, 2016. p. 229.

67 INTERNATIONAL COURT OF JUSTICE. Corfu Channel (United Kingdom v. Albania). Judgment, 1949. ICJ Reports p. 4, 18. 
'leave no room for reasonable doubt' ${ }^{\prime 6}$. Although the Court set forth a method for drawing inferences ${ }^{69}$, it established a high standard of proof for taking such inferences into consideration $^{70}$.

In the first Genocide case, Bosnia and Herzegovina affirmed that Serbia and Montenegro had a special duty of diligence in preventing genocide and that the proof of its lack of diligence could be inferred from fact and circumstantial evidence $^{71}$. Serbia and Montenegro had considered parts of relevant documents as being classified. In its judgment, the Court concluded that Serbia and Montenegro failed to prevent the genocide in Srebrenica, without it having had recourse to indirect proof or inferences. Indeed, the Court rejected the approach suggested by Bosnia and Herzegovina based on negative inferences ${ }^{72}$ and did not call upon Serbia

68 INTERNATIONAL COURT OF JUSTICE. Corfu Channel (United Kingdom v. Albania). Judgment, 1949. ICJ Reports p. 4, 18. For an analysis of the case, see FITZMAURICE, M. A. The Corfu Channel Case and the Development of International Law. In: ANDO, N. (Ed.). Liber Amicorum, Judge Shigeru Oda, 2002.

69 In its judgment in the Corfu Channel case, the Court delineated procedural and evidentiary rules, such as its position towards nonproduction of classified evidence, and the rules governing the use of circumstantial or indirect evidence. The ICJ also distinguished circumstantial evidence from 'direct proof' and considered that circumstantial evidence was a type of indirect evidence. See SCHARF, M. P.; DAY, M. The International Court of Justice's Treatment of Circumstantial Evidence and Adverse Inferences. Chicago Journal of International Law, vol. 13, n. 1, 2012. p. 125

70 TEITELBAUM, R. Recent Fact-Finding Developments at the International Court of Justice. The Law and Practice of International Court and Tribunals, Leiden, vol. 6, 2007. p. 136.

71 Reply of Bosnia and Herzegovina, in INTERNATIONAL COURT OF JUSTICE. Application of the Convention on the Prevention and Punishment of the Crime of Genocide (Bosnia and Herzegovina v Serbia and Montenegro). Judgment, 2007. ICJ Reports p. 43, 839, para 22.

72 For more details, see TEITELBAUM, R. Recent Fact-Finding Developments at the International Court of Justice. The Law and Practice of International 
and Montenegro to produce the requested documents ${ }^{73}$. It only stated that it noted 'the Applicant's suggestion that the Court may be free to draw its own conclusions ${ }^{74}$. However, no conclusions were drawn in that case. The second Genocide case, opposing Croatia to Serbia, followed the same path ${ }^{75}$, as the Court did not deviate from its ruling of 2007 in matters related to evidence ${ }^{76}$.

In these cases, although the situation was perfectly justifiable, the Court did not draw any adverse inference from refusals to reply to a request for information under Article 49 of its Statute. This has continued to be so in ICJ current practice, since the Court did not use its power to draw an adverse inference from Costa Rica's request for Nicaragua to provide evidence under its control in the recent Road and

\section{Court and Tribunals, Leiden, vol. 6, 2007. p. 138-9.}

73 INTERNATIONAL COURT OF JUSTICE. Application of the Convention on the Prevention and Punishment of the Crime of Genocide (Bosnia and Herzegovina v Serbia and Montenegro). Judgment, 2007. ICJ Reports p. 43, para 44 .

74 INTERNATIONAL COURT OF JUSTICE. Application of the Convention on the Prevention and Punishment of the Crime of Genocide (Bosnia and Herzegovina v Serbia and Montenegro). Judgment, 2007. ICJ Reports p. 43, 129, para 206. As pointed out by Vice-President Al-Khasawneh, in the absence of a request for production of documents, it was not up to the Court to take 'formal note' of a refusal under Article 49, INTERNATIONAL COURT OF JUSTICE. Application of the Convention on the Prevention and Punishment of the Crime of Genocide (Bosnia and Herzegovina v Serbia and Montenegro). Judgment, 2007. Dissenting opinion of Vice-President Al-Khasawneh. ICJ Reports p. 43, para 35.

75 INTERNATIONAL COURT OF JUSTICE. Application of the Convention on the Prevention and Punishment of the Crime of Genocide (Croatia v Serbia). Judgment, 2015. ICJ Reports p. 3.

76 See for further details on both Genocide cases, GATTINI, A.; CORTESI, G.. Some New Evidence on the ICJ's Treatment of Evidence: The Second Genocide Case. Leiden Journal of International Law, Cambridge, vol. 28, n. 4, p.899-913, 2015. p. 899 and GATTINI, A.. Evidentiary Issues in the ICJ's Genocide Judgment. Journal of International Criminal Justice, Oxford, vol. 5, n. 4, p.889-904, 2007. p. 889. 
Certain Activities cases ${ }^{77}$. To date, the ICJ has taken a soft stance towards nonproduction, without shifting the burden of proof or making adverse findings of fact ${ }^{78}$. These cases demonstrate that the Court is missing good opportunities to put into effect the powers attributed to it by the Statute and the Rules with regard to evidence ${ }^{79}$.

\section{A more active use of the Court's power to request information}

According to Art. 49 of the Statute, the Court may request the parties to produce of any documents or explanations. This article must be read in conjunction with Article 62 of the Rules, which clarifies that such evidence or explanation is 'necessary for the elucidation of any aspect of the matters in issue ${ }^{\prime 80}$. Art. 62 also addresses the possibility

77 First round of argument by Costa Rica in INTERNATIONAL COURT OF JUSTICE. Certain Activities Carried Out by Nicaragua in the Border Area (Costa Rica v. Nicaragua) and Construction of a Road in Costa Rica along the San Juan River (Nicaragua v. Costa Rica). Judgment: Merits, 2015. CR 2015/3, p. 63, para 35. Another example would be the INTERNATIONAL COURT OF JUSTICE. United States Diplomatic and Consular Staff in Tehran (United States of America v Iran). Judgment, 1980. ICJ Reports p. 10. For an analysis of other cases in which the Court has avoided making use of indirect reference by drawing inferences, see TEITELBAUM, R. Recent Fact-Finding Developments at the International Court of Justice. The Law and Practice of International Court and Tribunals, Leiden, vol. 6, 2007. p. 136-137. See also MALINTOPPI, L. Fact Finding and Evidence Before the International Court of Justice (Notably in Scientific-Related Disputes). Journal of International Dispute Settlement, Oxford, vol. 7, 2016. p. 425.

78 SCHARF, M. P.; DAY, M. The International Court of Justice's Treatment of Circumstantial Evidence and Adverse Inferences. Chicago Journal of International Law, vol. 13, n. 1, 2012. p. 128

79 INTERNATIONAL COURT OF JUSTICE. Application of the Convention on the Prevention and Punishment of the Crime of Genocide (Bosnia and Herzegovina v Serbia and Montenegro). Judgment, 2007. Dissenting Opinion of Judge ad hoc Mahiou. ICJ Reports p. 43, para. 61.

80 The procedure provided for Article 49 of the Statute and 62 of the Rules 
of the Court seeking proprio motu any other information for this purpose. However, such power is not binding upon the parties, as indicates the wording of Article 49 (the Court can 'call upon' parties to submit evidence) ${ }^{81}$. Drawing from the WTO practice ${ }^{82}$, it has already been suggested that the Court's jurisprudence could construe the binding character of its power to request information, based on a teleological interpretation of its Statute and Rules and on the duty of collaboration incumbent upon States for the collection of evidence $^{83}$.

Even if the Court's power to request information was to be binding on the parties, given the lack of enforcement mechanism of its requests, it could only have recourse to adverse inferences. This is not a new power to be conferred on the Court since Art. 49 of the Statute already provides the Court with the possibility of taking formal notice of any refusal to comply with its requests. The possibility of drawing adverse inferences, although never put in practice by the ICJ, is a common practice in other dispute settlement mechanisms, such as the WTO and the Iran-US Claims

was used for the first time by Italy in ELSI case (INTERNATIONAL COURT OF JUSTICE. Elettronica Sicula S.P.A. (ELSI) case (USA v. Italy). Pleadings, Vol. III 1987, p. 131, 432). See HIGHET, K.. Evidence, The Chamber and the ELSI Case. In: LILLICH, R B (Ed.). Fact-Finding before International Tribunals. Transnational Publishers, 1992. p. 42.

81 TAMS, C.. Article 49. In: ZIMMERMANN, A.; TOMUSCHAT, C.; OELLERSFRAHM, K. (Eds.). The Statute of the International Court of Justice: A Commentary. Oxford: OUP, 2006. p. 1107; SCHARF, M. P.; DAY, M. The International Court of Justice's Treatment of Circumstantial Evidence and Adverse Inferences. Chicago Journal of International Law, vol. 13, n. 1, 2012. p. 127, 150.

82 See WTO. Appellate Body. Canada - Measures Affecting the Export of Civilian Aircraft. Appellate Body Report, WT/ DS70/AB/R, 2 ago. 1999, para 187.

83 DEVANEY, J. G.. Fact-Finding before the International Court of Justice. Cambridge: Cambridge University Press, 2016. p. 180-187. 
Tribunal ${ }^{84}$, and other international criminal and human rights tribunals ${ }^{85}$.

As discussed above, the Court has not made significant use of its power (i) to request information under Article 49 of the Statute, nor developed a practice of granting discovery requests, i.e., (ii) requests by the parties. Much has been debated on the need for the Court to take a more proactive approach and make greater use of its fact-finding powers. As for requests made by the Court itself under Article 49 of the Statute, whenever a requested party fails to produce evidence, 'the Court could consider issuing a procedural order notifying the parties of its intention to draw an adverse inference in order to give the State an opportunity to comply 86 .

This problem is even more acute whenever the Court deals with the protection of fundamental values or community interests, such as the prohibition of genocide. Grave violations of human rights and acts of genocide are in breach of absolute prohibition of $j u s \operatorname{cogens}^{87}$. As highlighted

84 See HOLTZMANN. H.. Fact-Finding by the Iran-United States Claims Tribunal. In: LILLICH, R B (Ed.). Fact-Finding before International Tribunals. Transnational Publishers, 1992. p. 104.

85 For a collective analysis of the case law of the ICTR and the ICTY, as well as of the Inter-American Court of Human Rights (IACtHR), see INTERNATIONAL COURT OF JUSTICE. Application of the Convention on the Prevention and Punishment of the Crime of Genocide (Croatia v Serbia). Judgment, 2015. Dissenting Opinion of Judge Cançado Trindade. ICJ Reports p. 3, para. 98-115. See also DEVANEY, J. G.. Fact-Finding before the International Court of Justice. Cambridge: Cambridge University Press, 2016. p. 181.

86 Proposal advanced by Loretta Malintoppi, in CRAWFORD, J.; KEENE, A. Editorial. Journal of International Dispute Settlement, Oxford, vol. 7, 2016. p. 228. See also MALINTOPPI, L. Fact Finding and Evidence Before the International Court of Justice (Notably in Scientific-Related Disputes). Journal of International Dispute Settlement, Oxford, vol. 7, 2016. p. 426.

87 INTERNATIONAL COURT OF JUSTICE. Application of the Convention 
by Judge Cançado Trindade in his dissenting opinion in the second Genocide case, human rights tribunals feel obliged to resort, even more forcefully, to presumptions and inferences whenever 'the cases lodged with them disclose a pattern of widespread and systematic gross violations of human rights $^{88}$. The same might be applicable to the ICJ when it deals with global fundamental values. As a general proposal, the Court should be encouraged to draw adverse inferences, notably in cases involving community interests, in line with the jurisprudence of other international courts and tribunals.

Concerning requests made by the parties, the Court could also be more active in addressing requests for the disclosure of information. The issue has been hotly debated in the Genocide cases. The only exception is the ELSI case in which the United States was requested to make available to the Court a financial statement it had mentioned in the oral proceedings $^{89}$. The Italian counsel asked the Chamber to request the disclosure of such document, which was granted and performed by the President. As a result, the United States made available the requested document ${ }^{90}$.

on the Prevention and Punishment of the Crime of Genocide (Croatia v Serbia). Judgment, 2015. Dissenting Opinion of Judge Cançado Trindade. ICJ Reports p. 3, para. 83.

88 INTERNATIONAL COURT OF JUSTICE. Application of the Convention on the Prevention and Punishment of the Crime of Genocide (Croatia v Serbia). Judgment, 2015. Dissenting Opinion of Judge Cançado Trindade. ICJ Reports p. 3, para. 123.

89 INTERNATIONAL COURT OF JUSTICE. Elettronica Sicula S.P.A. (ELSI) case (USA v. Italy). Judgment, 1989. ICJ Reports, p. 15.

90 INTERNATIONAL COURT OF JUSTICE. Elettronica Sicula S.P.A. (ELSI) case (USA v. Italy). Verbatim Record C 3/CR 89/4 of 16 February 1989, p. 45. See for more details, DEVANEY, J. G.. Fact-Finding before the International Court of Justice. Cambridge: Cambridge University Press, 2016. p. 182-3. 
Drawing from its practice in the ELSI case, another possibility would be for the Court to make fuller use of the practice piloted in the ELSI case whereby requests for documents would be transmitted by the Court for it to be able to filter such requests. In order to put this in practice, Article 62 of the Court's Rules could be amended accordingly ${ }^{91}$. Needless to say that in cases involving community interests, the Court should make greater use of its powers to obtain evidence and engage actively with any objection to disclosure of documents before it. As put by Judge ad hoc Mahiou in his dissenting opinion in the first Genocide case, in face of grave accusation of genocide, 'it is therefore logical and to be expected that the Court should be called upon or that it should itself employ every means offered it by its Statute to arrive at clear findings on the authenticity or otherwise of alleged facts ${ }^{\prime 22}$.

\section{CONCLUSION}

There is no doubt that international adjudication contributes to the achievement of community interests. This paper addressed concrete procedural challenges and identified possible solutions so that the Court could be attuned to this new era of international adjudication, as highlighted by dissenting Judge Weeramantry in the Gabčíkovo-Nagymaros case ${ }^{93}$. The proposed amendments on

91 SARVARIAN, A. Preliminary Report. In: INTERNATIONAL LAW ASSOCIATION. Procedure of International Courts and Tribunals, 2017. (forthcoming) p. 77.

92 INTERNATIONAL COURT OF JUSTICE. Application of the Convention on the Prevention and Punishment of the Crime of Genocide (Bosnia and Herzegovina v Serbia and Montenegro). Judgment, 2007. Dissenting Opinion of Judge ad hoc Mahiou. ICJ Reports p. 43, para 59.

93 INTERNATIONAL COURT OF JUSTICE. Gabčíkovo-Nagymaros Project 
topics such as fact-finding and evidence were identified among specific reform proposals by the Counsel Survey conducted in preparation for the Seminar held on the 70th Anniversary of the Court's first inaugural sitting ${ }^{94}$. There were calls for 'greater transparency, a more interactive and less formalistic bench and increased openness to the practices and jurisprudence of other international tribunals, both on matters of substance and procedure ${ }^{\prime 95}$.

There is indeed a tendency towards further 'multilateralisation' of procedural law whenever community interests are at stake ${ }^{96}$. As pointed out by Judge Simma, 'international law is finally overcoming the legal as well as moral deficiencies of bilateralism and maturing into a much more socially conscious legal order ${ }^{\prime 97}$. This would enhance both the Court's 'normative' and 'democratic' legitimacy ${ }^{98}$. On the one hand, the normative conception of legitimacy

(Hungary v Slovakia). Judgment, 1997. Separate Opinion of Judge Weeramantry. ICJ Reports, p. 7, 118.

94 CRAWFORD, J.; KEENE, A. Editorial. Journal of International Dispute Settlement, Oxford, vol. 7, 2016. p. 225-30

95 CRAWFORD, J.; KEENE, A. Editorial. Journal of International Dispute Settlement, Oxford, vol. 7, 2016. p. 225.

96 BENZING, M.. Community Interests in the Procedure of International Courts and Tribunals. The Law \& Practice of International Courts and Tribunals, Leiden, vol. 5, n. 3, p. 369-408, 2006. p. 408.

97 SIMMA, B.. From Bilateralism to Community Interest in International Law. Leiden: Martinus Nijhoff, 1994. (Recueil des Cours de l'Académie de Droit International, 250). p. 234. According to Judge Simma, 'classic bilateralist international law has fallen far behind the present State of consciousness of international society' (234).

98 There is no authoritative or generally accepted definition of 'legitimacy' (FOLLESDAL, A. The Legitimacy Deficits of the Human Rights Judiciary: Elements and Implications of a Normative Theory. Theoretical Inquiries in Law, Tel Aviv, vol 14, n. 2, p. 339-360, 2013. p. 345). See also BEHN, D.; FAUCHALD, O. K.; LANGFORD, M. How to approach "legitimacy". Empirical Perspectives on the Legitimacy of International Investment Tribunals (book project), 2015. 
deals with 'the rightness of an institutions' exertion of power within a society' by defining 'a set of moral standards by which an institution or regime is judged or justified ${ }^{\prime 99}$. It is linked to 'legal legitimacy', which supposes the 'institution's observance of its legally constrained mandate' and includes 'the process by which rules, decisions, and actions are made, applied, or interpreted ${ }^{\prime 100}$. If ICTs fulfil certain criteria such as transparency, accountability and due process, they may be viewed as legitimate. On the other hand, aspects of 'normative' legitimacy are also taken into consideration when assessing the 'democratic legitimacy' of global institutions. Indeed, transparency, the participation of those affected and deliberation are of particular significance in building up the 'democratic legitimacy' of ICTs ${ }^{101}$. Rules on fact-finding and evidence are all of the utmost importance not only

99 BEHN, D.; FAUCHALD, O. K.; LANGFORD, M. How to approach "legitimacy". Empirical Perspectives on the Legitimacy of International Investment Tribunals (book project), 2015. For a definition of normative legitimacy, see BUCHANAN, A.; KEOHANE, R. O.. The Legitimacy of Global Governance Institutions. In: WOLFRUM, R.; RÖBEN, V. (Eds.). Legitimacy in International Law. Berlin, Heidelberg: Springer, 2008. (Beiträge zum ausländischen öffentlichen Recht und Völkerrecht, 194) p. 25-62. p. 25; FOLLESDAL, A. The Legitimacy Deficits of the Human Rights Judiciary: Elements and Implications of a Normative Theory. Theoretical Inquiries in Law, Tel Aviv, vol 14, n. 2, p. 339-360, 2013. p. 345; and HELFER, L. R.; ALTER, K. J. Legitimacy and Lawmaking: A Tale of Three International Courts. Theoretical Inquiries in Law, Tel Aviv, vol. 14, n. 2, 2013. p. 479; In order to access of discussion on international tribunals sentence's reception by national or supranational tribunals, see: HARRIS, Pamela Beth. Civil disobedience to international law: national fundamental rights resistance and the power of international constitutionalism. Revista Brasileira de Estudos Políticos, vol. 116, 2018.

100 BEHN, D.; FAUCHALD, O. K.; LANGFORD, M. How to approach "legitimacy". Empirical Perspectives on the Legitimacy of International Investment Tribunals (book project), 2015.

101 BOGDANDY, A. v.. The Democratic Legitimacy of International Courts: A Conceptual Framework. Theoretical Inquiries in Law, Tel Aviv, vol. 14, n. 2, p. 361-3779, 2013. p. 375. 
for protecting community interests, but also for ensuring the normative and democratic legitimation of ICTs, and in particular of the ICJ. It reflects a broad tendency towards a democratization of systems of global governance ${ }^{102}$.

\section{BIBLIOGRAPHY}

\section{Articles in journals}

ALVAREZ, J. E. Are International Judges Afraid of Science?: A Comment on Mbengue. Loyola of Los Angeles International and Comparative Law Review. vol.34, n. 1, 2011.

BENZING, M.. Community Interests in the Procedure of International Courts and Tribunals. The Law \& Practice of International Courts and Tribunals, Leiden, vol. 5, n. 3, p. 369-408, 2006.

BOGDANDY, A. v.. The Democratic Legitimacy of International Courts: A Conceptual Framework. Theoretical Inquiries in Law, Tel Aviv, vol. 14, n. 2, p. 361-3779, 2013.

BOGDANDY, A. v.; VENZKE, I. On the Democratic Legitimation of International Judicial Lawmaking. German Law Journal, Cambridge, vol. 12, n. 5, p. 1341-1370, 2011.

CRAWFORD, J.; KEENE, A. Editorial. Journal of International Dispute Settlement, Oxford, vol. 7, 2016.

FOLLESDAL, A. The Legitimacy Deficits of the Human Rights Judiciary: Elements and Implications of a Normative Theory. Theoretical Inquiries in Law, Tel Aviv, vol 14, n. 2, p. 339-360, 2013.

102 WHEATLEY, S. A Democratic Rule of International Law. The European Journal of International Law, vol 22, n. 2, 2011. p. 526-7. 
FOSTER, C. E.. New Clothes for the Emperor? Consultation of Experts by the International Court of Justice. Journal of International Dispute Settlement, Oxford, vol. 5, n. 1, p. 139-173, 2014.

GAJA, G. Assessing Expert Evidence in the ICJ. The Law and Practice of International Courts and Tribunals. vol. 15, 2016.

GATTINI, A.. Evidentiary Issues in the ICJ's Genocide Judgment. Journal of International Criminal Justice, Oxford, vol. 5, n. 4, p.889-904, 2007.

GATTINI, A.; CORTESI, G.. Some New Evidence on the ICJ's Treatment of Evidence: The Second Genocide Case. Leiden Journal of International Law, Cambridge, vol. 28, n. 4, p.899-913, 2015.

HELFER, L. R.; ALTER, K. J. Legitimacy and Lawmaking: A Tale of Three International Courts. Theoretical Inquiries in Law, Tel Aviv, vol. 14, n. 2, 2013.

KLEIN, N. S. Multilateral Disputes and the Doctrine of Necessary Parties in the East Timor Case. Yale Journal of International Law. vol, 21, n. 2, 1996.

LIMA, L. C. Expert Advisor or non-voting adjudicator? The potential function of assessors in the procedure of the international court of justice. Rivista di Diritto Internazionale. vol. 99, n. 4, 2016.

MALINTOPPI, L. Fact Finding and Evidence Before the International Court of Justice (Notably in Scientific-Related Disputes). Journal of International Dispute Settlement, Oxford, vol. 7, 2016.

MBENGUE, M. M.. International Courts and Tribunals as Fact-Finders: The Case of Scientific Fact-Finding in Interna- 
tional Adjudication. Loyola of Los Angeles International and Comparative Law Review. vol. 34, n. 1, 2011.

MBENGUE, M. M.. Scientific Fact-finding at the International Court of Justice: An Appraisal in the Aftermath of the Whaling Case. Leiden Journal of International Law. Cambridge, vol. 29, 2016.

MCWHINNEY, E. The International Court of Justice and International Law-Making: The Judicial Activism/Self-Restraint Antinomy. Chinese Journal of International Law. vol. 5, 2006.

NOLLKAMPER, A. International Adjudication of Global Public Goods: The Intersection of Substance and Procedure. The European Journal of International Law, vol. 23, n. 3, 2012.

PAYNE, C. Mastering the Evidence: Improving Fact Finding by International Courts. Environmental Law Review. vol. 41, 2011.

PEAT, D.. The Use of Court-Appointed Experts by the International Court of Justice. British Yearbook of International Law, Oxford, vol. 84, n. 1, p.271-303, 2014.

SANDOVAL COUSTASSE, J. G.; SWEENEY-SAMUELSON, E. Adjudicating Conflicts Over Resources: The ICJ's Treatment of Technical Evidence in the Pulp Mills Case. Goettingen Journal of International Law, vol. 3, n. 1, 2011.

SCHARF, M. P.; DAY, M. The International Court of Justice's Treatment of Circumstantial Evidence and Adverse Inferences. Chicago Journal of International Law, vol. 13, n. 1, 2012. TEITELBAUM, R. Recent Fact-Finding Developments at the International Court of Justice. The Law and Practice of International Court and Tribunals, Leiden, vol. 6, 2007. 
WHEATLEY, S. A Democratic Rule of International Law. The European Journal of International Law, vol 22, n. 2, 2011.

WOJCIKIEWICZ ALMEIDA, P. Enhancing ICJ procedures for litigating in the common interest: third-party intervention and amicus curiae briefs. Revista de Direito da Cidade, Rio de Janeiro, vol. 11, n. 1, 2019.

\section{Books}

BEHN, D.; FAUCHALD, O. K.; LANGFORD, M. How to approach "legitimacy". Empirical Perspectives on the Legitimacy of International Investment Tribunals (book project), 2015

BOGDANDY, A. v.; VENZKE, I. In Whose Name? A Public Law Theory of International Adjudication. Oxford: OUP, 2014.

CANÇADO TRINDADE, A. A.. International Law for Humankind: Towards a New Jus Gentium. Leiden, Boston: Martinus Nijhoff, 2010. (The Hague Academy of International Law Monographs, 6).

DEVANEY, J. G.. Fact-Finding before the International Court of Justice. Cambridge: Cambridge University Press, 2016.

FOSTER, C. E.. Science and the Precautionary Principle in International Courts and Tribunals. Expert Evidence, Burden of Proof and Finality. Cambridge: Cambridge University Press, 2011.

LAUTERPACHT, H.. The Development of International Law by the International Court. London: Stevens \& Sons Limited, 1958. 
ROSENNE, S. The Law and Practice of the International Court. Leiden: Martinus Nijhoff, 1985

SIMMA, B.. From Bilateralism to Community Interest in International Law. Leiden: Martinus Nijhoff, 1994. (Recueil des Cours de l'Académie de Droit International, 250). p. 233-242

\section{Book Chapters}

ALVAREZ, J. E. What Are International Judges For? The Main Functions of International Adjudication. In: ALTER, K. J.; ROMANO, C.; SHANY, Y. (Eds.). The Oxford Handbook of International Adjudication. OUP, 2014.

BUCHANAN, A.; KEOHANE, R. O.. The Legitimacy of Global Governance Institutions. In: WOLFRUM, R.; RÖBEN, V . (Eds.). Legitimacy in International Law. Berlin, Heidelberg: Springer, 2008. (Beiträge zum ausländischen öffentlichen Recht und Völkerrecht, 194) p. 25-62.

CANNIZZARO, E.; BONAFÉ, B. I. Of Rights and Remedies: Sovereign Immunity and Fundamental Human Rights. In: FASTENRATH, U.; GEIGER, R.; KHAN, D. et al (Eds.). From Bilateralism to Community Interest: Essays in Honour of Judge Bruno Simma. Oxford: OUP, 2011.

FITZMAURICE, M. A. The Corfu Channel Case and the Development of International Law. In: ANDO, N. (Ed.). Liber Amicorum, Judge Shigeru Oda, 2002.

FOSTER, C. E.. The Consultation of Independent Experts by International Courts and Tribunals in Health and Environmental Cases. In: KLABBERS, J. (Ed.). Finnish Yearbook of International Law. Oxford: Hart Publishing, 2009. v. 20. p. 391-420. 
HELFER, L. R.. The Effectiveness of International Adjudicators. In: ALTER, K. J.; ROMANO, C.; SHANY, Y. (Eds.). The Oxford Handbook of International Adjudication. OUP, 2014.

HIGHET, K.. Evidence, The Chamber and the ELSI Case. In: LILLICH, R B (Ed.). Fact-Finding before International Tribunals. Transnational Publishers, 1992.

HOLTZMANN. H.. Fact-Finding by the Iran-United States Claims Tribunal. In: LILLICH, R B (Ed.). Fact-Finding before International Tribunals. Transnational Publishers, 1992.

JENNINGS, R. Y. International Lawyers and the Progressive Development of International Law. In: MAKARCZYK, J. (Ed.). Theory of International at the Threshold of the $21^{\text {st }}$ Century: Essays in Honour of Krzystof Skubiszewski. Leiden: Matinus Nijhoff, 1996.

KLABBERS, J. The Community Interest in the Law of Treaties: Ambivalent Conceptions. In: FASTENRATH, U.; GEIGER, R.; KHAN, D. et al (Eds.). From Bilateralism to Community Interest: Essays in Honour of Judge Bruno Simma. Oxford: OUP, 2011.

LACHS, M. H.. Evidence in the Procedure of the International Court of Justice: Role of the Court. In: Bello, E. G.; Ajibola, B. A. (Eds.). Essays in Honour of Judge Taslim Olawale Elias. Leiden: Martinus Nijhoff, 1993.

MALJEAN-DUBOIS, S.; RICHARD, V. Pulp Mills on the River Uruguay (Argentina v. Uruguay), 2006. In: ALMEIDA, PAULA W; SOREL, JEAN-MARC. (Eds.). Latin America and the International Court of Justice: Contributions to International Law. Routledge, 2017

PALCHETTI, P. Opening the International Court of Justice to Third States: Intervention and Beyond. In: FROWEIN, J. 
A.; WOLFRUM, R. (Eds.). Max Planck Yearbook of United Nations Law. Kluwer Law International, 2002, vol. 6. p.139-181.

RIDDEL, A.. Scientific Evidence in the International Court of Justice - Problems and Possibilities. In: KLABBERS, J. (Ed.). Finnish Yearbook of International Law. Oxford: Hart Publishing, 2009. v. 20. p. 229-258.

SARVARIAN, A. Preliminary Report. In: INTERNATIONAL LAW ASSOCIATION. Procedure of International Courts and Tribunals, 2017. (forthcoming)

TAMS, C.. Article 49. In: ZIMMERMANN, A.; TOMUSCHAT, C.; OELLERS-FRAHM, K. (Eds.). The Statute of the International Court of Justice: A Commentary. Oxford: OUP, 2006.

TAMS, C.. Article 50. In: ZIMMERMANN, A.; TOMUSCHAT, C.; OELLERS-FRAHM, K. (Eds.). The Statute of the International Court of Justice: A Commentary. Oxford: OUP, 2006.

\section{Case Law}

COUVREUR, P. Le règlement juridictionnel. In SFDI (Ed.). Le processus de delimitation maritime: étude d'un cas fictif. Colloque international de Monaco du 27 au 29 mars 2003, 2004, p. 349, 384. Op. Cit. INTERNATIONAL COURT OF JUSTICE. Pulp Mills on the River Uruguay (Argentina v. Uruguay). Judgment, 2010. Joint Dissenting Opinion of Judges Al-Khasawneh and Simma. ICJ Reports p. 14

INTERNATIONAL COURT OF JUSTICE. Application of the Convention on the Prevention and Punishment of the Crime of Genocide (Bosnia and Herzegovina v Serbia and Montenegro). Judgment, 2007. ICJ Reports p.43 
INTERNATIONAL COURT OF JUSTICE. Application of the Convention on the Prevention and Punishment of the Crime of Genocide (Bosnia and Herzegovina v Serbia and Montenegro). Judgment, 2007. Dissenting opinion of Vice-President Al-Khasawneh. ICJ Reports p. 43

INTERNATIONAL COURT OF JUSTICE. Application of the Convention on the Prevention and Punishment of the Crime of Genocide (Bosnia and Herzegovina v Serbia and Montenegro). Judgment, 2007. Dissenting Opinion of Judge ad hoc Mahiou. ICJ Reports p. 43

INTERNATIONAL COURT OF JUSTICE. Application of the Convention on the Prevention and Punishment of the Crime of Genocide (Croatia v Serbia). Judgment, 2015. ICJ Reports p. 3.

INTERNATIONAL COURT OF JUSTICE. Application of the Convention on the Prevention and Punishment of the Crime of Genocide (Croatia v Serbia). Judgment, 2015. Dissenting Opinion of Judge Cançado Trindade. ICJ Reports p.3

INTERNATIONAL COURT OF JUSTICE. Case concerning the Temple of Preah Vihear (Cambodia v. Thailand). Judgment, 1962. Dissenting opinion of Judge Wellington Koo. ICJ Reports p. 6

INTERNATIONAL COURT OF JUSTICE. Certain Activities Carried Out by Nicaragua in the Border Area (Costa Rica v. Nicaragua) and Construction of a Road in Costa Rica along the San Juan River (Nicaragua v. Costa Rica). Judgment: Merits, 2015. ICJ Reports. 665.

INTERNATIONAL COURT OF JUSTICE. Corfu Channel (United Kingdom v. Albania). Order, 1948. ICJ Reports p. 124; 
INTERNATIONAL COURT OF JUSTICE. Corfu Channel (United Kingdom v. Albania). Order, 1949. ICJ Reports p. 237;

INTERNATIONAL COURT OF JUSTICE. Corfu Channel (United Kingdom v. Albania). Judgment, 1949. ICJ Reports p. 4

INTERNATIONAL COURT OF JUSTICE. Delimitation of the Maritime Boundary in the Gulf of Maine Area (Canada v. United States of America). Order: Appointment of Expert, 1984. ICJ Reports p. 165.

INTERNATIONAL COURT OF JUSTICE. Elettronica Sicula S.P.A. (ELSI) case (USA v. Italy). Judgment, 1989. ICJ Reports, p. 15

INTERNATIONAL COURT OF JUSTICE. Elettronica Sicula S.P.A. (ELSI) case (USA v. Italy). Verbatim Record C 3/CR 89/4 of 16 February 1989, p. 45.

INTERNATIONAL COURT OF JUSTICE. GabčíkovoNagymaros Project (Hungary v Slovakia). Judgment, 1997. ICJ Reports, p. 7.

INTERNATIONAL COURT OF JUSTICE. GabčíkovoNagymaros Project (Hungary v Slovakia). Judgment, 1997. Separate Opinion of Judge Weeramantry. ICJ Reports, p. 7 INTERNATIONAL COURT OF JUSTICE. Kasikili/Sedudu Island (Botswana v. Namibia). Judgment, 1999. Separate Opinion of Judge Oda. ICJ Rep p. 1045.

INTERNATIONAL COURT OF JUSTICE. Maritime Delimitation in the Caribbean Sea and the Pacific Ocean (Costa Rica v. Nicaragua). Order of 31 May 2016. ICJ Reports, para 4.

INTERNATIONAL COURT OF JUSTICE. Pulp Mills on the River Uruguay (Argentina v. Uruguay). Judgment, 2010. ICJ Reports p. 14. 
INTERNATIONAL COURT OF JUSTICE. Pulp Mills on the River Uruguay (Argentina v. Uruguay). Judgment, 2010. Separate opinion of Judge Keith. ICJ Reports p. 14

INTERNATIONAL COURT OF JUSTICE. Pulp Mills on the River Uruguay (Argentina v. Uruguay). Judgment, 2010. Separate opinion of Judge Cançado Trindade. ICJ Reports p. 14 INTERNATIONAL COURT OF JUSTICE. Pulp Mills on the River Uruguay (Argentina v. Uruguay). Judgment, 2010. Joint Dissenting Opinion of Judges Al-Khasawneh and Simma. ICJ Reports p. 14

INTERNATIONAL COURT OF JUSTICE. Pulp Mills on the River Uruguay (Argentina v. Uruguay). Judgment, 2010. Declaration of Judge Yusuf. ICJ Reports p. 14

INTERNATIONAL COURT OF JUSTICE. South West Africa (Ethiopia v South Africa; Liberia v South Africa). Judgment: Second Phase, 1966. ICJ Reports p. 6

INTERNATIONAL COURT OF JUSTICE. United States Diplomatic and Consular Staff in Tehran (United States of America v Iran). Judgment, 1980. ICJ Reports p. 10.

INTERNATIONAL COURT OF JUSTICE. Whaling in the Antarctic (Japan/Australia: New Zealand intervening). Judgment: Merits, 2014. ICJ Reports p. 226.

WTO. Appellate Body. Canada - Measures Affecting the Export of Civilian Aircraft. Appellate Body Report, WT/ DS70/AB/R, 2 ago. 1999.

\section{Documents}

HIGGINS, R. Speech by H.E. Judge Rosalyn Higgins to the Sixth Committee of the United Nations General Assembly. 2 nov. 2007. 
TOMKA. P. Speech by H.E. Judge Peter Tomka, President of the International Court of Justice, to the Sixth Committee of the United Nations General Assembly. 31 out. 2014.

Recebido em 04/12/2019

Aprovado em 15/07/2020

Paula Wojcikiewicz Almeida

E-mail: paulawalmeida@gmail.com 